\title{
"PREDICA MAL, QUIEN NO HABLA BIEN": LA ORATORIA CULTA DE ESPINOSA MEDRANO
}

\section{LA ORATORIA SAGRADA EN EL BARROCO}

La oratoria sagrada se halla íntimamente ligada -gracias, en principio, a san Agustín- a la retórica como arte de la elocuencia. Particularmente en el período que nos ocupa, la Contrarreforma, como explica Rafael Lapesa, se beneficia de todos los logros renacentistas en su contraofensiva a la influencia de la literatura profana, y aprovecha con fines religiosos sus mismas armas: el arte de la palabra ${ }^{1}$.

El Concilio de Trento había brindado pautas claras sobre la actividad de la predicación. Estas pautas, sumadas a las reglas retóricas que Espinosa Medrano conocía muy bien, ceñían, por un lado, el quehacer concionatorio, que debía ajustarse a esas normas y estaba vigilado de cerca. Por otro, pareciera que la profusión de motivos ornamentales y de autoridades, de lugares bíblicos y de fábulas paganas, etc., se expanden hasta el hartazgo derivando en otro objeto de cada corte (imagen similar a la "hidra vocal" de Gracián). La contorsión barroca hace que el concepto principal se vea rodeado y circunscripto por una profusa sintaxis o estructura del sermón. Pero no se suman elementos sin orden ni concierto -como pensaron en el neoclasicismo-, sino que todos los componentes están subordinados a un esqueleto preciso (el plan figurativo) del discurso, que no permite que el desarrollo se entorpezca, sino que calcula exactamente los movimientos, por lo menos en un maestro del estilo, como es Espinosa Medrano.

1 Historia de la lengua española, 9ª ed., Gredos, Madrid, 1981, p. 322. 
En sentido amplio, y teniendo en cuenta la cercanía que logran la retórica y la poética, los sermones forman parte de la literatura, compartiendo en gran medida sus mismos recursos estilísticos. Dice Francis Cerdán:

la sermonística puede y debe considerarse como una rama más de la literatura. El acercamiento a la predicación y al texto mismo de los sermones se justifica porque la oratoria sagrada es inseparable de la cultura literaria del Siglo de Oro en su conjunto. Pero, a su vez, la cultura es inseparable de la sociedad ${ }^{2}$.

\section{LUGAR DE LA ORATORIA SAGRADA EN LA SOCIEDAD BARROCA}

En la sociedad del siglo XVII, tanto en la metrópoli como en el floreciente virreinato del Perú, los sermones cumplían, junto con su función religiosa, un rol espectacular. Gran parte de la sociedad, de hecho, carecía de la habilidad de la lectura, por lo que sus medios de aprendizaje y de cultura eran los predicadores y las obras de teatro. Esto implica que el fenómeno adquiriera, en esta particular sociedad barroca, importantes singularidades. Como señala Cerdán: "Hay que pensar que entonces el sermón era, de la misma manera que la comedia, un fuerte polo de atracción de la vida socio-cultural" ${ }^{3}$. El mismo Hortensio Paravicino ya lo notaba en el siglo XVII: "por nuestra desgracia han llegado los sermones tan a la necesidad misma de agrado que las comedias"4.

Junto con el obvio objetivo doctrinal inherente al sermón desde sus inicios y el de persuadere, propio de la oratoria, están las prerrogativas contrarreformistas para acceder a lo más profundo de la voluntad del auditorio, la apelación a los distintos niveles emotivos del público, la necesidad de calar hondo en él mediante todos los artificios posibles. Además, la exigencia de preparación del Concilio de Trento llevaba a la necesidad de evidenciar el estudio, conocimiento y formación del predicador. Las citas de autoridad (que protegían de la censura inquisitorial) proliferaban, no sólo las de la Biblia y los Padres de la Iglesia, sino

2 "Actualidad de los estudios sobre oratoria sagrada del Siglo de Oro (1985-2002). Balance y perspectivas”, Criticón, 84/85 (2002), p. 23.

3 "La emergencia del estilo culto en la oratoria sagrada del siglo xvir", Criticón, 58 (1993), p. 63.

4 Oraciones, I, p. 176 apud Emilio Alarcos, "Los sermones de Paravicino", RFE, 24 (1937), p. 173, n. 3. 
también las de otros autores sagrados y profanos, constituyéndose en signo de erudición. Aun cuando las letras humanas no tenían el peso axiomático de las divinas, eran apreciadas y muy admiradas. Si bien la preceptiva sagrada se empeñaba en conservar el lugar de humildad y 'perfil bajo' de los predicadores, en la práctica el púlpito pasa a ser otro lugar de enunciación apropiado para la demostración de ingenio, conocimientos y novedad. De manera correlativa, el público esperaba ese despliegue y-aunque esto estaba censurado por todos los preceptistas-juzgaba y criticaba al predicador por su sermón. Como la necesidad de seducir al auditorio es primordial para cualquier orador, Francisco Terrones del Caño apunta que: "Y si no hay hombros ni caudal sino para tratar cosas muy vulgares, mejor es dejar el oficio; que están ya los auditorios tan acicalados que en predicándoles cosas muy comunes, las desprecian" .

También Diego de Estella se da cuenta de esto y propone predicar de manera novedosa o elegante aquellos asuntos que resultan comunes ${ }^{6}$, propuesta que alcanzará dimensiones extraordinarias durante el siglo XVII.

Es necesario considerar que el derrotero de la oratoria sagrada, como dijimos, sigue muy de cerca al de la literatura: la naturalidad renacentista cede ante el artificio barroco. De esta manera lo expresa Rodríguez de León en El predicador de Gentes, San Pablo (1638): "Los auditorios siguen a los santos, pero no dejan a los doctos, y salen del sermón con hastío si les falta el deleite con novedad... que aunque la verdad no se ha mudado, el estilo está muy diferente... siendo axioma de muchos, que predica mal, quien no habla bien"7.

La literatura pasaba por un proceso de cambio único, torsión del objetivo primordial que, en alguna medida, alcanza la oratoria: erudición ostentosa, agudeza conceptual y verbal que cambiaba la dirección del arte docente y de provecho moral hacia el goce estético.

La nueva poesía propiciaba polémicas, tratados, defensores, detractores, y algo muy similar sucedió en la oratoria sagrada. Aunque los estudios sobre ambas esferas aún están lejos de nivelarse, se conocen varias manifestaciones de la querella sobre el

5 Instrucción de predicadores, Espasa-Calpe, Madrid, 1946, cap. 2.

${ }^{6}$ Fray Diego de Estella, Modo de predicar y modus concionandi, CSIC, Madrid, 1951, p. 135.

7 El predicador de Gentes, San Pablo, Madrid, 1638, p. 97. 
lenguaje del púlpito en España, en la que se ataca o se defiende fervorosamente la predicación "culta". A diferencia de la predicación barroca en general, que según Cerdán hace foco y exagera la actio, la predicación "culta" no sólo abunda en cultismos, sino además en recursos sintácticos y rítmicos, en alusiones y metáforas: una poética.

\section{La oratoria sagrada en el Perú virreinal. Preceptos, CENSURAS, AUDITORIO}

En América, aunque resuenan ecos de la contienda en el Sermón de Sexagésima del padre Vieira, en el que éste se queja de lo remontada que era la lengua en el púlpito y pide llaneza ${ }^{8}$, la oratoria culta parece no haber tenido obstáculos para establecerse como práctica común. Las quejas, sin embargo, se proyectan en el futuro. En un manuscrito anónimo hallado por el padre Vargas Ugarte, que trata sobre oratoria española (y que, significativamente, tiene una parte titulada "Oratoria americana") explica el autor que no conoce el estado de la cuestión de la oratoria sagrada en Perú (sí de la de México, donde al parecer había residido, aunque Vargas Ugarte lo considera español), pero había escuchado de Espinosa Medrano, cuyos sermones, dice:

subidos de estilo se pasean por esas nubes, motivando desvelos, acreditando empeños, acrisolando finezas, brillando auroras, derritiendo cristales, desmayando jazmines, bostezando primaveras y otras mil indignidades de éstas que recogió el P. Vieyra, en la censura de su Sermón de Sexagésima y lo más vergonzoso y escandaloso es que acinados estos disparates, se dieron a luz en Madrid, en un tomo de a folio, con este arrogante título: La Novena Maravilla...9.

La queja era una; y la causa, el precepto principal de la retórica: la adecuación al auditorio. Si el público buscaba en el sermón un deleite paralelo al que perseguía en el corral de comedias, no estaba el predicador en posición de negárselo, pues corría

8 Cf. Luis Jaime Cisneros, “Antonio Vieyra: un hombre y un estilo”, en Literatura portuguesa. Del legado clásico al Modernismo, Embajada del Portugal en el Perú, Lima, s.f., pp. 23-41.

9 Apud Rubén Vargas Ugarte, La elocuencia sagrada en el Perú en los siglos XVII y XVIII, Academia Peruana de la Lengua, Lima, 1942, p. 18. 
el riesgo de no ser atendido y de no lograr conmoverlo con un estilo más plano. Al lado de la cita de Terrones de Caño sobre los auditorios acicalados, podemos leer, de la pluma del P. Martín de Jáuregui en la Catedral de Lima en 1674, contemporáneo a los sermones de La novena maravilla:

Antiguamente, iban a la inteligencia de los lugares, ya se van a la hermosura de las voces, juzgando que aunque están demás en los conceptos, no son lo menos, pues honra lo que arrastra. Desta suerte se han ido variando los usos y temo que se introduzca también la chamberga en los sermones. Hoy, pues, corre el uso de respetar por muy entendido al auditorio y así se insinúa solamente la Historia del Evangelio, ciñéndose en sus cláusulas el Predicador cuanto lo sufre la misma inteligencia. De este desconcierto grande que nos arrebata a todos los Predicadores, tienen la culpa los oyentes, porque antiguamente no era agravio explicarles el fondo de la Escritura, en que cada palabra es diamante que tiene muchos; ya es este empeño desatención, porque presumen que nada se les va por alto y que, al vuelo, apuntan adonde ha de herir la destreza del Predicador. Antiguamente gustaban de oír las Historias Sagradas, ya tienen tan estragado el gusto que les causan fastidio. Voime, pues, con ellos, que he oído decir que vestir al uso, aunque sea a lo pobre, es lucimiento... ${ }^{10}$.

\section{Auditorio}

Es conocido el hecho de que el mercado hispanoamericano recibía con fervor las obras clásicas del Siglo de Oro español y, como demuestran las investigaciones de Irving Leonard, Hampe Martínez y otros, los libros cruzaban el océano con muy poco tiempo de diferencia desde su publicación, además de que se celebraban reuniones y tertulias en el interior del círculo más culto.

Sonia Rose estudia la conformación de una élite letrada en territorio indiano, aduciendo que el acceso (restringido) a la cultura sucede desde muy temprano. La autora se concentra en la creación de las academias como lugar de legitimación e intercambio de los letrados y, asimismo, de intento de emulación de la vida cultural de la corte. En el mismo sentido, Colombí Monguió propone aunar los gestos que puedan parecer particu-

10 ApudVargas Ugarte, op. cit., p. 21. 
laridades individuales (abundancia de citas de autoridad, exhibición desmesurada, y muchas veces no de primera mano, de erudición, imitatio de clásicos y reelaboración de tópicos, motivos y temas tradicionales, etc.) en "variantes del discurso humanista", que les garantizaba su identidad cultural como miembros de la res publica de los studia humanitatis ${ }^{11}$.

Pensando en el sector del auditorio que no poseía una biblioteca particular o directamente en el público analfabeto, tenemos datos sobre las obras de teatro representadas (y no las obras de teatro escolar, compuestas y representadas en el interior de los colegios y seminarios o universidades), muchas de Lope de Vega, Calderón y otros autores dramáticos que, para el caso, podrían llamarse "del estilo" (comedia nueva). Si en los recursos compositivos solían encontrarse algunos de estos motivos culturales humanistas y barrocos (como la reelaboración del material clásico, abundantes juegos de palabras y galas de ingenio), en lo que se refiere a la lengua utilizada -aun cuando la construcción, siempre poética, pueda ser más sencilla que el estilo gongorino de las Soledades-, Inmaculada Delgado Cobos demuestra que el recuento de cultismos en las comedias de Lope arroja un número mucho mayor al de las obras de Góngora, con lo que se puede suponer una familiarización incluso del público no especializado con este tipo de lenguaje más pomposo y culto que se imponía como una moda, tanto en el teatro como en el púlpito.

Este tipo de práctica sirve al predicador, además, en "el contexto cultural en la Colonia [que] constituye un medio difícil y agresivo"12, para los fines de la autolegitimación y reconocimiento de sus pares, con quienes comparte las desventajas de vivir alejados de España, desventajas que buscan paliar justamente con la valoración del propio talento, equiparable al peninsular. En este sentido, adquiere importancia la relevancia que se le otorga al criterio del público europeo, a cuyo reconocimiento también aspiraba el letrado colonial ${ }^{13}$, como puede verse en la Dedicato-

11 Alicia Colombí Monguió, "Erudición humanista en saber omnicomprensivo e identidad colonial”, en La formación de la cultura virreinal. T. 1: La etapa inicial, eds. Karl Kohut y Sonia Rose, Iberoamericana-Vervuert, Frankfurt-Madrid, 2000, p. 75.

12 Eduardo Hopkins Rodríguez, "La problemática del receptor en Juan Espinosa Medrano”, Homenaje a Luis Jaime Cisneros, PUCP, Lima, 2002, p. 973.

13 Eduardo Hopkins Rodríguez, Poética colonial, PUCP, Lima, 2003, p. 22. 
ria de López Dávalos de los Sermones varios que dixo en el Perú de Hernando de Herrera a Pedro Portocarrero:

Este pues genial afecto del suelo patrio ${ }^{14}$, me ha tenido en todos tiempos tan deseoso de ver represa[e]ntar en el teatro de Europa tan eminentes sugetos, è ingenios grandes en todas ciencias, como aquel cielo produce, quando lastimado de que en tan retirado Orbe representen solos, y sin testigos talentos tales, sin más teatro, que su conciencia, aunque sea éste el mejor para el aplauso de su virtud $^{15}$.

Aun cuando el razonamiento más piadoso considera que la conciencia es el mejor lugar para juzgar el talento, para que Perú quedase honrado, el claro objetivo es Europa, pues "con ninguna cosa se honra más una Patria, que con los Sabios [aunque] siempre les dificulta su misma cuna" (p. 4).

\section{Los Sermones de Espinosa Medrano. Objetivos. ELECCIONES}

Los sermones que predicaba Espinosa Medrano, el Lunarejo, en Cuzco durante la segunda mitad del siglo XVII -teniendo en cuenta que nos han llegado sólo panegíricos que pertenecen al género epidíctico y que permitían un lenguaje más ornado y elevado que los estrictamente morales- parecen ser en sí mismos un arma de defensa y alarde. Incluso cuando es opinión aceptada que el público que acudía a escuchar los sermones era variado ${ }^{16}$, y que los niveles de recepción, aunque diversos, alcanzaban la totalidad del auditorio, lo cierto es que continuamente hay marcas que direccionan el discurso erudito al sector más elevado

14 "La alusión al concepto de patria para designar a América como entidad diferente de Europa, y la referencia al valor equiparable de los ingenios americanos con los del viejo mundo, constituyen un tema fundamental en nuestra historia" (ibid., p. 34).

15 Hernando de Herrera, Sermones varios, Antonio Lacavalleria, Barcelona, 1675 , p. 3.

16 Cf. José Antonio Rodríguez Garrido, "Aproximación a la oratoria sagrada de Espinosa Medrano”, Boletín del Instituto Riva Agüero, 15 (1988), 11-32; E. Hopkins Rodríguez, art. cit.; y Luis Jaime Cisneros, "Sobre Espinosa Medrano: predicador, músico y poeta”, Cielo Abierto, 1984, núm. 28, pp. 3-8 y "Para estudiar el sermonario de Espinosa Medrano", ALM, 35 (1997), 157-165. 
del público, el letrado, sus pares, los "maiores": "lo que priva es la conciencia de que el sermón es un evidente espectáculo para entendidos, un lujo del espíritu. No parece estar previsto otro tipo de interlocutor", indica Cisneros ${ }^{17}$. En este sentido, señalamos unas pocas marcas en los sermones del Lunarejo:

Coligiò pues à posteriori (como dezís los Lógicos) lindamente Gregorio (p. 22a).

Què es esto señores? (p. 57a).

Escuchadme Theólogos (p. 60).

escuchad Theólogos una profundidad de el Abad Ruperto (p. 100).

no os parezca Retóricos, que esto sólo es Prosopopeya (p. 105).

En todos los casos citados, el autor hace una exposición de su capacidad erudita y apela al grupo al que va dirigida esa alusión (aunque también la explica para aquel receptor que no es especialista). Se trata de un movimiento mediante el cual se establece una red de pares, cuyo lazo de unión es la calidad intelectual. A diferencia de las exposiciones enciclopédicas -que también las hay en abundancia-, éstas demuestran un uso personal del entendimiento, no un catálogo de saberes presentes también en una poliantea.

El Lunarejo se esforzaba por lograr que sus piezas concionatorias fueran un "lujo del espíritu" que satisficiera los requisitos a los que el público estaba acostumbrado, dada la vida cultural que se respiraba en el interior de la ciudad letrada y más allá también; y que, igualmente, cumplieran con la tendencia barroca de asombrar e innovar. Porque, como apunta Emilio Alarcos para el caso español: "el público cortesano acudía a los sermones, más que en busca de enseñanza y adoctrinamiento moral y religioso, en demanda de deleite literario" 18 . Los predicadores, inmersos como estaban en la corriente cultural de la época, iban detrás de ese objetivo literario, sin que el lucimiento de una lograda elocuencia fuera en desmedro de la profundidad de contenidos doctrinales.

17 “Sobre Espinosa Medrano...”, p. 4.

18 Art. cit., p. 173. 
Este clima aparece ilustrado en la anécdota consignada por Agustín Cortés de la Cruz en su prólogo a La novena maravilla: "El P. Iuan de Mena, de la Compañía de Iesús, Cathedrático de Theoloía, sapientíssimo, cada vez que predicava el Doctor, dezía à su compañero: Padre, coja su manteo, y vamos à oír cosas que nunca hemos oído" 19 .

No sólo las explicaciones, sino también la sensualidad de la frase permiten llegar, por medio de los sentidos, incluso a quienes no 'penetran' en un alto nivel de interpretación, oponiendo un modo de persuasión por el lado del goce de la voluntad y no por el de la razón.

\section{RECURSOS CULTOS Y CONCEPTISTAS EN LOS SERMONES DEL LUNAREJO}

De acuerdo con la estilística, el significado no es ya sólo un concepto, sino que además puede "representar dos o tres conceptos simultáneamente, como ocurre en la metáfora y también en el chiste basado en juegos de palabras. Quien no entienda esto no comprenderá nada de gran parte de la literatura del Siglo de Oro" ${ }^{20}$.

En poesía o en prosa, los elementos constructivos, formales - la ubicación de ciertas vocales en determinados puntos rítmicos, el orden de las palabras, el uso de su poder evocativo, un cultismo, la aliteración de algunas consonantes, toda fórmula estilística, todo recurso retórico, en fin- tienen una función estética, expresiva. La relación entre el significado y el significante no es arbitraria, sino que tiene su motivación. La estilística partiría de la idea de que si cada expresión idiomática tiene una significación fijada por el idioma, posee también un complejo de poderes sugestivos, fijados asimismo por el idioma.

Esta relación fue perfectamente intuida o conocida por el Lunarejo, y eso está presente no sólo en su labor creativa, sino también en su labor crítica. En el famoso Apologético en favor de D.

19 La novena maravilla nuebamente hallada en los Panegíricos sagrados qen varias Festividades dixo el Sor. Arcediano Dor. D. Iuan de Espinosa Medrano primer Canónigo Magistral Tesorero Chantre y finalmente Arcediano de la Cathedral del Cuzco en los Reynos del Pirú, por Joseph de Rueda, Valladolid, 1695, p. ii.

20 Dámaso Alonso, Poesía española. Ensayo de métodos y límites estilísticos. Garcilaso, Fray Luis de León, San Juan de la Cruz, Góngora, Lope de Vega, Quevedo, Gredos, Madrid, 1950, p. 22, n. 4. 
Luis de Góngora, defendió el uso del hipérbaton en Góngora (tan censurado por algunos de sus contemporáneos, centro mismo de sátiras y burlas de sus detractores), no como un recurso exterior que adorna la poesía y puede separarse de ella, sino dando debida cuenta de la motivación de tal fenómeno estilístico y su natural relación con la poesía.

\section{Consideraciones Generales SOBRE EL ESTILO} DE LOS SERMONES DE ESPINOSA MEDRANO

Las demandas del auditorio vistas supra repercutían en el impulso de composición de los sermones, que tendían a las complejidades barrocas y al refinamiento expresivo e ingenioso que en la época se marcaban, no sólo en la estructura ${ }^{21}$, sino sobre todo en la elocutio, en la que nos centraremos para ofrecer una aproximación al estudio del sistema expresivo de Espinosa Medrano. Si bien estamos conscientes de que lo que nos llega es "lengua muerta”, y sólo una parte de lo que realmente fue la prédica de un sermón (como el texto de una comedia), creemos que no es ocioso indagar en la parte escrita y, no es un dato menor, publicada (lo que quiere decir que el compendio esperaba lectores), para detenernos en algunos usos y recursos que, incluso, siendo parte del código en boga, estaban marcados por el uso particular de la pluma del Lunarejo. El discurrir de sus sermones es sinuoso, en éste propone el tema y lo prueba desde ángulos diversos, atento al deleite del auditorio, para el que ofrece todo su caudal de conocimientos humanistas, teológicos y escriturarios. De las obras en castellano que conocemos del Lunarejo, $L a$ novena maravilla es la única que contiene piezas para un público general. Como dijo Luis Jaime Cisneros: "un estudio del sistema expresivo de Juan de Espinosa Medrano atrae por la posibilidad de iluminar aspectos mal conocidos de la lengua culta de nuestro siglo XVII"22.

La elocuencia atenderá, de acuerdo con la preceptiva retórica, tanto a res como a verba. Además de lo conceptual y del contenido que sería desarrollado en el sermón, debían considerarse los principios eufónicos y rítmicos, dado el carácter oral del discurso. Fray Diego Valadés indica que: "La elocución tendrá ele-

${ }^{21}$ Cf. J. A. Rodríguez Garrido, art. cit., pp. 28 y ss.

22 "Para estudiar el sermonario...", p. 157. 
gancia $^{23}$, disposición ${ }^{24}$ y dignidad ${ }^{25}$ ". En la prosa concionatoria, confluyen el estilo propio de las composiciones morales áureas (sentencioso y grave) con elementos más característicos del discurso oral, que deben alivianar y hacer más amena la escucha; y, claro, con el gusto de la época.

Si la materia a predicar exige un tono solemne, demorado, que dé tiempo a la reflexión y al examen interior, la presencia de un público que mover y "sacudir" impone algunos golpes de efecto que se dirijan a la voluntad y no sólo al entendimiento. Los sermones de Espinosa Medrano, a pesar de las reconvenciones en las preceptivas y de su propia declaración, según la cual "se distingue la Escritura humana y Poësía secular de la revelada, y Theológica: que está, empoçando mysterios, descoge humildes las cláusulas y llano el estilo; y aquélla, toda adorno de dicciones, toda pompa de palabras, toda aliño de eloquencias iace vana, hueca, vacía, y sin coraçón de mysterio alguno"26; progresan lenta y sinuosamente, adornados con repeticiones, paralelismos, epítetos y aposiciones; se vuelven sobre sí mismos en antítesis y quiasmos; y se retardan en perífrasis retumbantes y en otras fórmulas estilísticas.

Cuán lejos está la prosa sagrada del Lunarejo de tener "humildes las cláusulas y llano el estilo" y de sustraerse de las improntas barrocas de sorprender y deleitar podrá vislumbrarse, esperamos, en lo que resta de este trabajo, donde tomará relieve el estilo que apoya y enriquece la significación.

Iremos viendo, acompañados de pocos, pero representativos ejemplos, los distintos componentes más característicos de su prosa y los dispositivos que el predicador utiliza para la consecución exitosa del o de los objetivos (no sólo el persuadere religioso, sino, de manera concomitante y no exenta de relación con ese mismo objetivo, la autolegitimización como parte de la república de las letras). El paralelismo, que se verá en primer lugar y que aparece como rasgo notable en la prosa de Espinosa Medrano, es harto frecuente en las Sagradas Escrituras y en los Padres de la Iglesia que comúnmente cita el autor, tales como

${ }^{23}$ Dicc. Aut.: eficaz y grave compostura de estilo; hermosura, gentileza, adorno y buen arte.

${ }^{24}$ Dicc. Aut.: proporción y simetría.

${ }_{25}$ Dicc. Aut.: excelencia o realce.

${ }^{26}$ Apologético en favor de D. Luis de Góngora, Imprenta de Juan de Quevedo y Zarate, Lima, 1694, p. 13. 
san Agustín ${ }^{27}$, Tertuliano y san Pedro Crisólogo. De este modo, puede pensarse en su utilización como una especie de instinto rítmico o memoria auditiva, aunque las reiteradas explicaciones sobre asuntos de discurso y figuras retóricas, amén de su conocida calidad literaria, nos orienta hacia la idea de un uso magistral y consciente de las posibilidades de la lengua.

La armonía y el ritmo discursivo del Lunarejo son rasgos sobresalientes que se perciben desde una primera lectura. El ritmo prosaico no obedece ya al numerus latino, sino que tiene lugar merced a otros aspectos que muestran una regularidad general, una periodicidad, que es el concepto básico del ritmo; así, se encuentran semejanzas, aunque no necesariamente idénticas, en la longitud silábica, en la disposición de los acentos, en la fonética o en la estructura oracional.

RECURSOS MÁS NOTORIOS EN LA NOVENA MARAVILLA

\section{Paralelismo}

La figura básica que reúne un tipo de estructuras simétricas en su estructura oracional es el isocolon, o, modernamente, paralelismo ${ }^{28}$, es decir, la correspondencia sintáctica de la composición de dos o más partes. La figura consiste en la yuxtaposición de varios miembros cuyos elementos respectivos tienen el mismo orden. Si bien la ordenación de las partes es paralela, puede haber relajaciones. Por ejemplo, el quiasmo, constituido por la inversión de los elementos en los miembros, o el zeugma, que evita la repetición de todos los elementos, aunque la presupone.

Esta figura hace que la prosa sea de dilatada progresión, sosegada y grave. Dámaso Alonso habla de "sintagmas no progresivos", que son los no lineales, los que se bifurcan. Son, apunta Alonso, visualizándolos espacial y no temporalmente, "como un río cuyo curso se demora subdividiéndose en brazos que a su

27 Dice Ernst Robert Curtius acerca de las Confesiones: "Su estilo es prosa artística antigua. Los medios de la retórica antigua entran aquí al servicio del nuevo mundo espiritual cristiano. San Agustín emplea principalmente tres de los recursos.... el isocolon..., el antitheton... y el homoioteleuton..." (Literatura europea y Edad Media latina, trads. M. Frenk y A. Alatorre, F.C.E., México, 1955, p. 115).

28 Heinrich Lausberg, Elementos de retórica literaria, Gredos, Madrid, 1975 , p. 168 . 
vez pueden subdividirse" ${ }^{29}$. Si en algunas ocasiones tal duplicación de estructuras puede servir para completar el concepto, hay en estos sermones numerosos casos de subdivisiones aparentemente ociosas. La acumulación de miembros o de voces que con frecuencia son sinónimas provoca una abundancia muchas veces tautológica, ornamental, pero que sirve para influir en los afectos de los oyentes, otorgando mayor vehemencia a la frase. Quintiliano, de hecho, enumera esta figura entre aquellas que pueden dar fuerza al concepto y excitar los ánimos ${ }^{30}$. A veces se produce un refuerzo en el plano fónico, lo que hace al paralelismo más denso; en otras, como dijimos, la simetría extrema se aligera con alguna leve variación.

El paralelismo tiene dos tipos de figuras fundamentales: la enumeración y la antítesis. Dentro de la enumeración, hay acumulación o sinonimia, y ambas participan de la amplificatio, concepto retórico que tiene una función primordial a la hora de mover los ánimos, mediante el énfasis o tratamiento reforzado del tema.

La enumeración acumulativa presenta, como es de esperarse, realidades distintas entre sí, aunque -en los casos a los que nos referimos- compuestos y ordenados por elementos que tienen algún tipo de correspondencia y que, generalmente, también vienen acompañados por alguna de las figuras de repetición: aliteraciones, anáfora, epífora, complexio, etc., y de omisión: zeugma, asíndeton:

mal se cansarà envejezido en la corrupción de las obleas; mal fallecerà corrompido en la antigüedad de los accidentes (p. 12b).

le parecerían años las horas, lustros los días, siglos los meses (p. 11a).

Dale gracias el cielo con sus ángeles, astros, rayos, nubes, y pluvias: la tierra con sus hombres, árboles, montes, y ríos: el piélago con sus rocas, tempestades, hondas, y pezes (p. 65b).

El esquema de diseminación y recolección agrega otra complejidad y adorno al discurso, y en el ejemplo que sigue se combina,

29 Dámaso Alonso y Carlos Bousoño, Seis calas en la expresión literaria española, Gredos, Madrid, 1951, p. 25.

${ }^{30}$ M. Fabio Quintiliano, Instituciones Oratorias, trad., ed. y notas según la edición de Rollin, Imprenta de la Administración del Real Arbitrio de Beneficencia, Madrid, 1799, p. 120. 
además, con una estructura de sentido quiásmica: "Pues si los Ángeles le bendicen, bendito serà Dios en los Ángeles; si el Sol, Luna, y Estrellas le alaban, alabado serà en las Estrellas, Luna y Sol” (p. 66a).

En estos casos, la función amplificadora se da por la acumulación de elementos que apoyan una idea, muchas veces dispuestos con una cierta gradación que realza aún más la gracia de la figura del isocolon: "Este pan renovado, si que es la Eternidad de el amor, el alimento de los Ángeles, el néctar de los Espíritus, la nieve de el Thabor, el Cristal de los Cielos, el Rozío de las Luzes, el Manà de la Eternidad" (p. 14b).

\section{Sinonimia}

Pero lo más común en nuestro autor es que utilice el paralelismo entre sintagmas que, quizás con algún leve matiz diferente, están diciendo básicamente lo mismo. Por un lado, la figura de dicción sería la expolición o interpretación: serie de pensamientos semejantes en cuanto al sentido, pero diferentes en la manera de expresarse. La identidad formal, en estos casos, otorga armazón a la idea y ayuda a grabar el mensaje en el ánimo del que escucha. Por otro lado, la figura de la acumulación de miembros ya es de por sí causante de cierto efecto, y si lo es de elementos sinónimos la ponderación del objeto es muy notable. Sin embargo, la sensación remanente es que el paralelismo plurimembre obedece, en gran medida, a criterios eufónicos y rítmicos.

Veamos, por ejemplo, el caso de este período en el que consta una plurimembración paralelística hipotáctica. Estamos a 6 de agosto, la fiesta de la Renovación del sacramento, donde se pone de relieve la eternidad del amor de Dios:

A1) si el Amor, B1) que se califica ardiente, C1) no fenece à los yelos de la muerte; A2) si el afecto, B2) que se obstenta encendido, C2) no caduca à las decrepitudes del tiempo; no se contente pues el de su Magestad, en aver cifrado sus finezas en su muerte, sino que D1) repita esse morir por tantos siglos, D2) reitere essa passión por tantas edades (p. 12b).

El extracto tiene además, en este caso, dos endecasílabos perfectamente construidos: "no fenece à los yelos de la muerte" y "repita esse morir por tantos siglos", donde los tres acentos rítmicos caen en la misma vocal. 
Frecuentemente el autor apoya y refuerza esta simetría de estructuras, según dijimos, con aliteraciones, ubicadas, por lo general, en el mismo lugar o acento de las frases paralelas:

se distile en raudales, o se desate en arroyos (p. 13a).

Què han de ser, si no rebosos de aquel Cuerpo Sacramentado? Què han de ser, si no disfrazes de aquel fuego escondido... (p. 14a).

no es más que nieve empedernida, no es más que carámbano emperezado (p. 14b).

preparando oídos, previniendo atenciones (p. 38b).

En este otro ejemplo, las frases paralelas con aliteración adquieren un matiz de contraste temporal entre nivel terrenal y celestial: "Antes arrastrava montañas, y peñascos, agora se arrebata los Astros, y los Planetas" (p. 47b).

Veamos un extracto en el que puede apreciarse esa cadencia lenta, dada por la proliferación de subordinadas y de paralelismos binarios que realzan lo dicho. Es el comienzo de la tercera parte del mismo sermón:

Y si por acreditar incorruptible su Pan, y blasonar de Eterno su Amor, nos combida su Magestad à competencias de el tiempo con lo nuevo de aquel Sacramento, que ingratitud sería, no aplaudirle la invención, ò no repetirle la novedad: Estimámosla como Celestial, quando temiendo, que se nos envejezca, la defendemos de el poder de la corrupción. Bien podía Dios preservar de ella aquel Pan, pues aun el Manà, con ser tan dañable, que de un día à otro se tornava en gusanos, llegando el Viernes, durava dos días, y en el Arca de el Testamento se conservò incorrupto por largos siglos; no quiere Dios esso, no gusta, de que su Cuerpo dure, quedando siempre uno en la especie, si no, que su duración se vincule en la remuda, su Eternidad en la innovación; à esso atendió el Concilio Turonense, mandando, se renovasse de siete en siete días: ...No sea, que acontezca (tal nunca suceda) que al Soberano Pan se le atreva el gusano, ò le embista el moho (p. 15a).

"Y si por acreditar incorruptible su pan, y blasonar de Eterno su Amor”. Aquí, de acuerdo con la identificación entre maná y pasión de Cristo que el autor hizo en las primeras partes del 
sermón, está diciendo lo mismo, así como en "no aplaudirle la invención, ò no repetirle la novedad". Justamente, las preceptivas llaman a esta figura "sinonimia". Son necesidades de un ritmo en especial, dual, cadente, sinuoso: "que su duración se vincule en la remuda, su Eternidad en la innovación”, regodeo en las posibilidades de la lengua que se manifiesta en grande con el epifonema ornamental entre paréntesis para terminar en una aparente disyuntiva, cuya estructura encierra, otra vez, dos maneras ligeramente diferentes de decir lo mismo, al igual que en "la vestidura, ò túnica soberana" (p. 17b), donde aprovecha la figura de expolición para introducir un cultismo ${ }^{31}$ (lo mismo que arriba "incorruptible") como una de las opciones. El mismo tipo de desarrollo puede verse en estos pasajes:

Cansarse de amar, porque la muerte lo acaba todo con el vivir, no es más, que querer hasta espirar. Acabarse el querer, porque el tiempo lo consume todo con su durar, no es más, que amar hasta morir. Porfiar con la muerte, à quien más puede, es la mayor valentía del amor; competir con el tiempo, à quien más dura, es la mayor fineza de la afición (p. 11).

\section{Contrarios o antítesis}

Así como encontramos las afirmaciones expresadas de manera dual o plural, en que los miembros son casi análogos entre sí, también la realidad se plantea mediante el uso de estructuras sintácticas paralelísticas, pero en parejas antitéticas. Esta disposición bimembre está, evidentemente, en la base de la formación de períodos y del ritmo de la frase.

La antítesis se conforma a partir de la contraposición de dos realidades opuestas, expresadas mediante palabras aisladas o frases enteras. Fray Diego de Estella aconseja "hablar por contrarios" (p. xxx), y Luis de Granada señala que "en la proporción de los contrarios... hay tanto donaire y gracejo que, de cualquier modo que los contrarios se junten, adornan grandemente la

31 De paso no deja 'túnica' solamente, sino que, poniendo el vocablo culto (Inmaculada Delgado Cobos, El cultismo en la oratoria sagrada del Siglo de Oro: 1580-1633, Universidad Complutense, Madrid, 1987, p. 194) junto a su equivalente popular, no deja dudas en el auditorio. 
oración, y no sólo la hacen gustosa, sino eficaz"32. Es un recurso que otorga mucha fuerza al discurso y de esa manera actúa en el plano de la voluntad afectiva. El choque entre la organización formal simétrica o paralela y la oposición semántica de los miembros es un contraste que enriquece el sermón y refuerza su capacidad persuasiva. En vista de la importancia otorgada en las retóricas a la antítesis, esto es generalmente admitido en todas las épocas. Pero es innegable la importancia que la figura adquiere en el Barroco, altamente encarecida por Gracián en su Agudeza y arte de ingenio: "Éste [las 'ponderaciones de contrariedad'] es el concepto que más le cuesta al ingenio... Unir a fuerza de discurso dos contradictorios extremos, extremo arguye de sutileza... La hermosa antítesis fue siempre artificiosa prevención de esta agudeza"33.

Esta figura del antitheton puede presentarse en oraciones, en grupos de palabras y en palabras aisladas, en relación de coordinación o de subordinación. Los matices adoptan diferentes modos; por ejemplo, se subraya la oposición léxica (que es la base de la figura), usando el esquema del isocolon paralelo que comentamos antes. Por ejemplo, en el sermón panegírico que Espinosa Medrano dedica al Augustísimo Sacramento propone que la muerte de Cristo es vida para nosotros. El contraste está primero en el concepto hilador, a partir del cual se estructura el resto de los opósitos. Esta manera de expresión no hace otra cosa que mostrar el carácter paradójico que encierra la vida humana con el estilo sentencioso que caracteriza este tipo de discurso moral. La visión católica, además, fundamenta gran parte de su eficacia en la necesidad de que tal cosa ocurra, en el "equilibrio' que eso supone. Enseguida lo deja explícito:

No ay felicidad sin sobresalto (Augustíssima, y Divina Magestad Sacramentada) no ay gozo sin susto, ni júbilo sin pesar. No ay deleite sin riesgo, flor sin veneno, ni vida sin muerte (p. 2a).

La estructura paralelística permite una comunión de opuestos en la que todos los elementos están concertados; una estructura única en la que cohabitan los contrarios: "No es de suyo más dulce por Misericordioso que azedo por justiciero" (p. 40b).

32 Luis de Granada, Retórica eclesiástica, en Obras completas, trad. José Climent, ed. Álvaro Huerga, FUE-Dominicos de Andalucía, Madrid, 1999, t. 23, p. 179.

${ }_{33}$ Agudeza y arte de ingenio, Espasa Calpe, Buenos Aires, 1942, pp. 58-60. 
De esta manera, el predicador trabaja en los planos de la voluntad y de la inteligencia, nivelando el sufrimiento con la felicidad y reforzando, de esa manera, la exhortación cristiana con la resignación, ya que Cristo "con morir la vida, hizo espirar a la muerte" (p. 3b). La igualdad externa se manifiesta, incluso, como un contraste frente a la contraposición del contenido conceptual: "Yà excita la ira, yà persuade la clemencia, yà agasaja el sueño, y lo repele, yà atrae cuydados, y también los quita" (p. 38b).

Para resaltar la gracia de María, el autor también apela a la antítesis y a la expresividad de las fórmulas vistas. Mientras que abundan los adjetivos luctuosos y los adverbios que enfatizan la totalidad del sufrir, en el caso de la concepción de los hombres, el regocijo llena la descripción de la de María, reforzada por la repetición de la alegría:

La Concepción de María como fausta, como pura anuncia al Mundo los gozos, y júbilos, que malogrò la culpa; y cuando en las demàs concepciones de los hombres, por fúnebres, todo es lamentos, todo maldiciones, todo gemidos... La de María es nuncio feliz de las alegrías del universo, principio alegre de la ventura de los siglos (p. 52b).

\section{Correctio}

Es ésta una figura que forma parte de las figuras dialécticas, características de la disputatio. Mediante la correctio, el orador niega o rechaza la palabra o concepto que propone al inicio para sustituirlo por otro más preciso. En este punto, señalamos algunos casos en los que el elemento sustituto no es una corrección o mejoramiento, sino la negación de su contrario. De esta manera, se intensifica la expresión y se despliega un modo de amplificatio que acentúa la frase.

Un procedimiento muy característico de este tipo de prosa áurea que estamos describiendo es que avanza por pares o varios miembros, como en este fragmento, en el que, después de combinar distintos modos de presentar los contrarios, termina el período con dos miembros isosilábicos y de idéntica acentuación:

me parece estraño, y aun monstruoso linage, ser la madre Paloma, y nacer Azor el Alma. Es Ave de amor la Paloma; mansa, no rapante; pacífica, no vandolera; no suena iras, si no arrullos; no esgrime 
garras, si no serenidades: Como pues le nace un ánima Gerifalte, ò páxaro de rapiña? (p. 24a).

Esta manera de afirmar con una fórmula fija, que es a la vez antitética, y en la que se niega algo, tiene valor intensificador y es muy común en la obra del Lunarejo. De este modo, está presente el término opuesto y no sólo se encarece por afirmación, sino que también, rechazando lo contrario, otorga todavía más fuerza a la idea:

no las cantò; si no, que las regañò ò las bramò (p. 40a).

Blasón lustroso... q' no la ponen à que la solape celemin embidioso, si no à que la obstente candelero brillante (p. 241a).

Vemos a continuación cómo insistiendo en uno de los dos términos del contraste, lo ardiente, se prepara el terreno para un mayor impacto y relieve del término opuesto, lo frío. Paralelismos simétricos, aliteraciones, metáforas y cultismos son los recursos poéticos que se emplean para describir la ascensión de Jesús al Tabor con sus discípulos para que ocurra la Transfiguración:

no quedò à tanto rayo collado, que no brillasse reflexos, risco que no centelleasse luzeros: ardiòse el Monte en luzes; abrasòse en arreboles el Thabor, y al lucido incendio de glorias aparecieron junto à èl Moysés; y Elías, Mariposas de tanta lumbre, Salamandras de tanto explendor: ...La vestidura, ò túnica soberana, quizàs temerosa de resolverse en pavesas, alentò valentías contra el fuego, pues en candidezes de nieve rebatiò las puntas de tanta llama (p. 17b).

Sutil oposición que repetirá enseguida en otro bimembre paralelo: "Trocar en nieve el ropage, disfraçar el rostro en Sol" (p. 18a), usando el mismo mecanismo que vimos antes, y que aparece frecuentemente: el de suspender el primero de los miembros del paralelismo de manera paroxítona y rematar el segundo en final oxítono; en el ejemplo anterior aparece en dos pares paralelos:

ardiòse el Monte en luzes; abrasòse en arreboles el Thabor y

Mariposas de tanta lumbre, Salamandras de tanto explendor (p. 17b). 
Dentro también del amplio marco de la antítesis, tiene gran presencia la paradoja u oxímoron. No nos interesa aquí una delimitación de ambos conceptos, sino su funcionalidad más general para el período que nos ocupa. Si las contrariedades le parecían a Gracián una gran manifestación de ingenio y sutileza, la cohabitación de contrarios que se excluyen en un mismo elemento pondera aún más el discurso:

ardiendo el Sol en centellas de el Estío, elava también, nevándose à copos el Invierno (p. 14a).

muerte dulce (p. 4a).

cadáver vivo (p. 4a).

El autor propone y subraya el oxímoron, además, en una estructura quiásmica que, elegante, relaja y cierra la estructura paralela: "Mis muertos viviràn, resucitaràn tus difuntos" (p. 13b). Aquí, aunque sigue el paralelismo sintáctico de los miembros, forma quiasmo el sentido:

Si es Exército, cómo es Coro? y si es capilla, cómo era escuadrõ? (p. 39b).

Buelta la llama en rozío, trocado en marea el incendio (p. 65b).

Plantel de la muerte, tosigo de la vida (p. 56b).

La gradatio también se presenta de manera frecuente. Estamos ya en otro tipo de ritmo, en el que la acumulación lineal de elementos vuelve dinámica la prosa, por lo que la gradatio produce el golpe de efecto: "Este pan renovado, si que es la Eternidad de el Amor, el alimento de los Ángeles, el néctar de los Espíritus, la nieve de el Thabor, el Cristal de los Cielos, el Rozío de las luces, el Manà de la Eternidad" (p. 14b).

En el caso de la gradatio con verbos, se llama 'disolución' y se presenta en forma asindética, agiliza el modus dicendi-generalmente después de un leve retardo-y precipita al auditorio a la captación, evitando la distensión: "Aspid que enroscado dormía entre las matas despierta, espeluzando las escamas de el cuello, embiste, pica, y mata" (p. 2a).

$\mathrm{O}$, frente a lo demorado de algunos períodos, usa oraciones breves que se presentan generalmente en una narración: 
"Yà sabeis la historia. Nadie acertò la adivinança. Sobornaron la Novia, revelò el secreto, perdiòse la apuesta, y explicòse el Problema" (p. 3b). De esta manera, la atención no desciende, quedando siempre en un nivel alto, y causa profunda impresión en quien lo escucha.

\section{Repetición}

La repetición, vista como virtud y no como vicio, es una fuente de donde manan recursos retóricos literarios. Para destacar una idea, es común recurrir a la duplicación de un mismo vocablo u otros de la misma familia o raíz; por ejemplo, el concepto de totalidad en el sermón panegírico primero a santo Tomás de Aquino:

Y esso era resplandecer tanta Estrella en la cabeça del Toro, tantos ingenios de Santos Padres, tantos entendimientos de Agustinos, Gerónimos, y Chrysóstomos, como no avían de brillar al quaxarse de todos una lumbrera total en aquella su mente angélica? Tomás luze por todos, entiende con todos, habla por todos, explícalos todos... (p. 241b, el subrayado es mío).

Así, generalmente en una estructura paralela (no siempre con la rigidez del isocolon, sino muchas veces aligerado por el zeugma o las inversiones quiásmicas), con epanalepsis (comenzar y terminar con la misma palabra): "Muchos reparos son essos, y cuidados muchos" (p. 2b). También logrando retruécanos:

Pues ésse será su juego; que si el juego es exercicio del gusto, no son las delicias si no gusto del exercicio (p. 50b).

què buelta es ésta tan de priesa, què priesa es ésta tan cierta para la buelta? (p. 18a).

\section{Equívocos}

En este ámbito de las repeticiones se encuentran recursos muy propios del Barroco: la paronomasia, la dilogía, equívocos, retruécanos y juegos de palabras en general. Es bien sabido que en el siglo XVII abundaba este tipo de agudeza verbal, "que consiste más en la palabra; de tal modo, que si aquélla se quita, no 
queda alma, ni se pueden ésas traducir en otra lengua; de este género son los equívocos..." (Gracián, p. 21). Es característico que las repeticiones no se limiten a la literatura satírica y burlesca, sino que aparezcan, y más a menudo de lo que el gusto del siglo XXI entiende, en la literatura religiosa.

Gracián escribe sobre la palabra de esta manera: "Es como hidra vocal una dicción, pues a más de su propia y directa significación, si la cortan o la trastruecan, de cada sílaba renace una sutileza ingeniosa y de cada acento un concepto" (p. 211). Es evidente que el público correspondía a (y pedía) este tipo de composiciones, ya que la poesía, la literatura emblemática, los sermones y el teatro estaban llenos de ese uso de la palabra. Como declara Lope en el Arte nuevo:
Siempre el habla equívoca ha tenido y aquella incertidumbre anfibológica, gran lugar en el vulgo, porque piensa, que él sólo entiende lo que el otro dice (vv. 322-325).

El tipo de procedimientos desplegados para la captación del auditorio no difiere demasiado en el teatro y en el púlpito. Aun cuando el fin religioso principal de la predicación estaba bien claro, sobre todo en el Nuevo Mundo a partir del concilio tridentino, lo cierto es que, en gran medida, el sermón resultaba, antes que nada, un espectáculo de deleite. Este segundo objetivo de toda retórica -delectare-, a juzgar por testimonios de la época (censuras, poesías satíricas, reconvenciones en las preceptivas) había cobrado relieve sobre los otros dos, docere y movere. Con este marco, todos los recursos enristrados por los escritores barrocos para saciar la sed de novedad y admiración del público se hicieron usuales en los escritos religiosos y, particularmente, en los sermones. De manera que estas piezas, fuertemente codificadas desde la antigüedad, se manifiestan en esta época -no podía ser de otra manera-inmersas en la tradición discursiva propia del Barroco, como estamos intentando demostrar para el caso de Juan Espinosa Medrano. Si bien es cierto que en sus piezas oratorias no abunda el tipo de recursos de agudeza verbal (como es de esperarse en un discurso grave y solemne), la pericia con que el Lunarejo manejaba la lengua le permite incluir algunos pocos recursos que dan donaire y gracia al sermón, pero sin salirse de los preceptos en ese sentido. 


\section{Paronomasia}

En esta tradición discursiva, la paronomasia se presenta generalmente como un efecto de agudeza verbal menor, una ingeniosidad superficial en la que se aproximan dos parónimos cuya diferencia en el significado y similitud en el significante producen el asombro de quien escucha. Apunta Gracián: "Consiste el artificio de estos conceptos en trocar alguna letra o sílaba de la palabra o nombre, para sacarla a otra significación, ya en encomio, ya en sátira" (p. 218).

Cuanto mayor es la distancia entre ambos significados, tanto más efectista será el recurso. Veamos, por ejemplo, en los sermones de La novena maravilla.

María es quien canta, y encanta à Dios (p. 38b).

no se recava el espirar con el mismo respirar (p. 22b).

Aquí, combinado con el retruécano: "Pero una barra de hierro, yerro avía de ser, si bien el de Adàn fue yerro, que passò la barra" (p. 6b).

Su eficacia aumenta si la paronomasia aparece contenida en estructura de isocolon o similar, como cuando hablando de la actitud de Dios respecto de nosotros, los pecadores, dice: "Que si bolvemos a llamarle, rebuelve al punto; si à desenojarle tornamos, perdona agravios, repite cariños, derrama dádivas, hasta que nuestro desprecio le arroja, ni falta à las puntualidades del despacho, ni acierta con los retiros del despecho" (p. 27b).

Y qué decir si se combina con antítesis: el poder mnemotécnico y el efecto de la sorpresa puede ser aún mayor: "que es aquel combite recuerdo de su combate" (p. 6a).

\section{Dilogía}

Otro de los recursos del equívoco, que Fernando Lázaro Carreter $^{34}$ considera el pináculo de los recursos, es la dilogía: un "significar a dos luces", en palabras de Gracián: "Válese aquí de las dos significaciones que ambas le convienen, y es como doble la sutileza; repítese dos veces en alguna ocasión la palabra

34 Estilo barroco y personalidad creadora, Cátedra, Madrid, 1974, p. 13. 
equívoca, exprimiendo en la una la significación, y la otra en la otra" (p. 14). Espinosa Medrano lo utiliza con fines cómicos en su obra de teatro Amar su propia muerte, como era lo corriente en boca de los graciosos. En los sermones, sin embargo, no tiene esa finalidad, sino la de darle un giro ingenioso y fresco a la narración; por ejemplo, hablando de Jacob y Raquel, dice de aquél: "Perdido andaba por la hermosura de la prima, si ya no era por la prima de la hermosura" (p. 11a). Y refiriéndose a Luzbel: "Término de altivez, ò sobervia sin término" (p. 29a). O donde también se logra un retruécano: "Trepan con fatiga la sublime cuesta, que si cuesta trabajo el subir con Dios, más os cuesta baxar con Satanàs" (p. 17b).

Hablando de diamantes, rubíes, amatistas y otras piedras, aprovechando la doble significación de ripio como cascote o resto de material y como palabras vanas o sin sustancia, explica: "Cuéntanse de ella historias raras, prodigios admirables curiosidades exquisitas, que os divirtieran, si yo gastara ripio aun de piedras tan preciosas" (p. 86b).

Otro rasgo que sobresale en la lectura de los sermones es el uso de los cultismos que, por su enorme frecuencia y por su calidad, merecerían un trabajo aparte. El autor no sólo elige aquellos que ya habían pasado al acervo cultural general, por el teatro u otras formas de transmisión oral, sino que además consigna muchos cultismos más raros, como 'fomes' (p. 54a), 'voz puramente latina', según el Dicc. Aut. (1730), y que es muy difícil encontrar en nuestra lengua. Terreros y Pando lo consigna en su Diccionario castellano con las voces de ciencias y artes y sus correspondientes de las tres lenguas (1787) como indisociable del sintagma latino fomes peccati, que se refiere al pecado de la concupiscencia. Así sucede también con opificio (p. 52b), que aún hoy no se encuentra en ningún diccionario. Es posible que varios sean de su propia invención ('numerosamente', por ejemplo). A menudo el Lunarejo usa formas cultas en alternancia con la forma evolucionada, como mancha/macula, lluvia/pluvia, macho/ masculo, entre muchos otros pares. Otros cultismos, si no gongorinos sí asociados a esa corriente culta popularizada por el poeta cordobés, tienen también una marcada presencia. 'Esplendor' aparece con una frecuencia altísima en los sermones, y era el vocablo más censurado por Barahona de Soto en su soneto "Contra un poeta que usaba mucho de estas voces". El poema satírico comienza con la palabra "Esplendores", luego repite "otra vez esplendores", en el séptimo verso nuevamente "otra y 
quinientas veces esplendores, / más esplendores” y tres versos más abajo "de esplendor otro poquito" 35 . Lo mismo pasa con piélago, fineza, cadáver, crédito, canoro, cándido, armonía, fausto, funesto, céfiro, cóncavo, fatal, ilustre, por mencionar sólo algunos de los cultismos censurados que usa con mucha frecuencia el Lunarejo.

De la gran abundancia de cultismos que se registran en los sermones del Lunarejo, algunos de ellos fueron introducidos en el siglo XV, otros en el XVI y otros son más recientes, según el catálogo de cultismos de Inmaculada Delgado Cobos. Al respecto, explica la investigadora: "Los términos cultos introducidos en siglos anteriores son necesarios no sólo como reflejo de una tradición arraigada, y cuyo conocimiento responde al gusto de los «mejores», sino en tanto cumplen el papel básico de denominación de conceptos que siguen viviendo en la época" (p. 2684).

A esto, que viene de alguna manera a confirmar nuestro planteamiento acerca del uso de las posibilidades de la lengua y de la cultura para autolegitimarse como parte de la elite letrada, agregamos las necesidades eufónicas y el gusto por las sonoridades esdrújulas y latinas, al que responde en gran medida la elección de tantos cultismos ("álamo húmedo de la luziente resina", p. 4a): vínculo, víbora, públicamente, lámina, nocturno, piélago, círculos, símbolo, pálida, diáfano, cándido, por mencionar sólo algunos de los cultismos que aparecen en la primera parte del primer sermón de La novena maravilla. La frecuencia de latinismos es altísima, como podemos observar en dos pequeños fragmentos que pertenecen al mismo sermón, en los que subrayamos esas voces: "Para obstentar el vencimiento de el sepulcro, para pompa del triunfo" (p. 4b). O en las perífrasis con las que invoca a las monjas del Convento de Santa Catalina: "A vosotras digo, cándido vulgo de Serafines, Luzida constelación de purezas, mejor porción de los rebaños de Christo, Ángeles humanos, Estrellas canoras, que solemnizais à María concibiendo al Verbo, Celebridad muy digna de Virgines" (p. 48a).

En muchos casos el predicador repite antes o después la idea con palabras más vulgares, como en

La de María es nuncio feliz de las alegrías del universo, principio alegre de la ventura de los siglos (p. 52b).

35 D. Alonso, La lengua poética de Góngora (parte primera, corregida), CSIC (RFH, anejo 20), Madrid, 1950, pp. 87-88. 
las sombras de la embidia los avía obscurecido yà, y borrádoles la lumbre (p. 238a).

le son fausto anuncio, fortunado agüero de las claríssimas medras (p. 246b).

Pero hay también un gran número que no es explicado ni aclarado, lo que permite entender que el léxico culto era ampliamente utilizado -y comprendido- en varios sectores de la sociedad virreinal peruana.

La elección del léxico culto en general entraña una voluntad de refinamiento que hace buscar alternativas al léxico inveterado. En los epítetos, esta elección se manifiesta claramente. Aunque no podamos precisar el grado de extrañeza de los vocablos, la abundancia de cultismos hallada permite percibir un criterio aristocrático, en el que las palabras se eligen cuidadosamente por sus aspectos formales y melodiosos y por su capacidad de expresión: "húmidos luceros" (p. 4b), "cándida Açucena" (p. 4b), "herética perfidia" (p. 240b), "congeturas crédulas" (p. 38a), "místico novillo" (p. 37), "porción etérea" (p. 38a), "ignorancia incrédula" (p. 43b), "túnica cerúlea" (p. 65a).

Tarea ardua sería hacer un recuento de los cultismos que aparecen en el compendio de los sermones. Abunda este tipo de epíteto presentado, como también los epítetos superlativos, que ponderan el objeto de la atribución en grado hiperbólico y que, además, son proparoxítonos; hay cultismos de acepción y alta frecuencia de cultismos caros a Góngora, como canoro, purpúreo, raudo.

Muchos de sus epítetos ${ }^{36}$ cultos provienen del grupo de palabras latinas con terminaciones -alis, -ales y, según Rosa Perelmúter Pérez, resultaban muy novedosos en aquel momento (en el del Primero Sueño-1692-; por lo tanto, con más razón en años anteriores): racional, celestial, victoriales, intelectual, natural, entre otros. Hay presencia, asimismo, de cultismos sintácticos: gran cantidad de hipérbatos ("và el Rey de las Abejas de gotas de oro de Divinidad salpicado", p. 4b, o del tipo: "En esta pues Música espiritual”, p. 45b), algunas fórmulas “A, si B” y similares ("tan poderosa, si dulce mano", p. 245a), construcciones abso-

${ }^{36}$ La epítesis, "gran parte del aliño del estilo”, según Gracián, es otro recurso ampliamente utilizado por nuestro autor, pero cuyo análisis no conviene aquí por ser excesivamente largo. 
lutas de varios tipos, como "todo melodías la voz, todo gorgeos el acento" (p. 52b). Este tipo de sintaxis funciona en el discurso como un ornato, un remedo de la lengua latina que distingue a la lengua escrita de la lengua coloquial. Es decir, que intervendrían recursos que pertenecen al registro de la escritura en un discurso oral, y esto enaltece el sermón, le otorga distinción, lo hace más culto, y viene, por lo tanto, en consonancia con otros recursos que aristocratizan la prosa del Lunarejo.

Pudimos pasar breve revista, de este modo, por algunos de los procedimientos, mediante los cuales Espinosa Medrano convierte el discurso sagrado en un deleite barroco para los sentidos; explicamos también cómo expresa los asuntos remanidos y predicados tantas veces en modos sorprendentes y los torna un entretenimiento para el auditorio, que lejos de escandalizarse por esa práctica (censurada en las preceptivas, aunque común en lo cotidiano) la exigían y celebraban.

Julia Sabena

Universidad Nacional de Rosario Consejo Nacional de Investigaciones Científicas y Técnicas 